Published in final edited form as:

Curr Top Dev Biol. 2008 ; 82: 23-53. doi:10.1016/S0070-2153(07)00002-6.

\title{
The Erythroblastic Island
}

\author{
Deepa Manwani ${ }^{\star}, \dagger$ and James J. Bieker ${ }^{\dagger}$ \\ *Schneider Children's Hospital, New York 11040 \\ †The Brookdale Department of Molecular, Cell and Developmental Biology, Mount Sinai School of \\ Medicine, New York 10029
}

\begin{abstract}
Erythroblastic islands are specialized microenvironmental compartments within which definitive mammalian erythroblasts proliferate and differentiate. These islands consist of a central macrophage that extends cytoplasmic protrusions to a ring of surrounding erythroblasts. The interaction of cells within the erythroblastic island is essential for both early and late stages of erythroid maturation. It has been proposed that early in erythroid maturation the macrophages provide nutrients, proliferative and survival signals to the erythroblasts, and phagocytose extruded erythroblast nuclei at the conclusion of erythroid maturation. There is also accumulating evidence for the role of macrophages in promoting enucleation itself. The central macrophages are identified by their unique immunophenotypic signature. Their pronounced adhesive properties, ability for avid endocytosis, lack of respiratory bursts, and consequent release of toxic oxidative species, make them perfectly adapted to function as nurse cells. Both macrophages and erythroblasts display adhesive interactions that maintain island integrity, and elucidating these details is an area of intense interest and investigation. Such interactions enable regulatory feedback within islands via cross talk between cells and also trigger intracellular signaling pathways that regulate gene expression. An additional control mechanism for cellular growth within the erythroblastic islands is through the modulation of apoptosis via feedback loops between mature and immature erythroblasts and between macrophages and immature erythroblasts.

The focus of this chapter is to outline the mechanisms by which erythroblastic islands aid erythropoiesis, review the historical data surrounding their discovery, and highlight important unanswered questions.
\end{abstract}

\section{Introduction}

Hematopoiesis is the process by which a self-renewing population of stem cells provides a continuous replenishment of differentiated blood cells by generating progeny with sequentially altered gene expression patterns (Kondo et al., 2003; Orkin, 2000). As this process proceeds, there is progressive restriction in potential, first generating lineagerestricted progenitors, then morphologically identifiable precursors, and finally the mature blood cells. The very first site of hematopoiesis occurs in the yolk sac and provides primitive erythrocytes that are essential for the survival of the embryo until the next, definitive wave of hematopoiesis is established (Tavassoli, 1991). The sites of definitive erythropoiesis are the fetal liver and postnatal bone marrow, and occur in three distinct stages. The first stage is the evolution of lineage-committed progenitors that are microscopically invisible (Emerson et al., 1985; Rosse, 1976). Identification relies on a selective enrichment via cell surface markers combined with culture and in vivo cellular assays. The earliest recognizable erythroid-specific progenitor is the burst-forming unit erythroid (BFU-E) that in semisolid media gives rise to large colonies of red blood cells (RBCs), identifiable between 7 and 10 days after plating of murine-derived cells. BFU-E generates colony-forming unit erythroid (CFU-E). The later progenitors can also give rise to 
colonies of RBCs; however, they are smaller and tighter and arise within 2-3 days of culture. CFU-E expresses the erythropoietin receptor and can give rise to the characteristic colonies in the presence of erythropoietin alone (Axelrad et al., 1974).

The second stage of erythroid differentiation consists of morphologically identifiable nucleated precursors that progress from the proerythroblast to basophilic, polychromatophilic, and orthochromatic forms (Granick and Levere, 1964). In mammals, four distinctive processes characterize the progression through these stages: accumulation of hemoglobin contributing to the change from basophilic to acidophilic cytoplasm in more mature forms, expansion of erythroblast numbers through a limited number of cell divisions, a progressive decrease in cell size, and progressive nuclear condensation and enucleation (Granick and Levere, 1964). This second stage occurs when the erythroblasts are in physical contact with a macrophage.

The third and final stage of erythroid differentiation involves the maturation of the reticulocytes into circulating erythrocytes. The reticulocytes dismantle their ribosomal machinery, expel organelles, and assume a biconcave discoid shape. These mature erythrocytes then circulate in the blood stream until senescent, when they are removed by the macrophages within the reticuloendothelial system (Gifford et al., 2006).

In contrast to definitive erythropoiesis in the fetal liver, primitive erythroblasts arising from the yolk sac were thought to retain their nuclei and diverge in the second and third stages of erythroblast maturation. More recently, evidence for enucleation of primitive erythroblasts has been uncovered and for the persistence of these enucleated forms later into gestation than previously described (Fraser et al., 2007; Kingsley et al., 2004). Thus, there are many more parallels between the stages of maturation of primitive and definitive erythroblasts than previously conceived.

Marcel Bessis first described erythroblastic islands, the specialized micro-environmental compartments within which mammalian erythroblasts proliferate and differentiate during their second stage of maturation (Bessis, 1958). These islands consist of a central macrophage that extends cytoplasmic protrusions (Gifford et al., 2006) to a ring of surrounding erythroblasts. Twenty years later, after extensive studies to delineate the biological significance of these structures (Bessis and Breton-Gorius, 1961, 1962; Keyhani and Bessis, 1969; Policard and Bessis, 1962), he concluded that "the anatomic existence of the erythroblastic island consisting of the central histiocyte and rings of erythroblasts surrounding it, the fact that the histiocyte does phagocytose nuclei extruded by late erythroid cells, and the close contact between the two, strongly suggest that the erythroblastic island may constitute an example of an 'ecologic niche', a sociologic notion applied to cytology, which contributes to the maturation of RBCs. This is as much as can be said at the moment" (Bessis et al., 1978). Another two decades later, our current understanding has substantially advanced and the appeal for sociological analogies has withheld the passage of time. As noted by James Palis, "no red cell is an island" (Palis, 2004) and indeed extensive macrophage-erythroblast and erythroblast-erythroblast adhesive interactions are necessary for a thriving definitive erythropoietic community. Whether maturation of primitive erythroblasts also occurs in proximity with macrophages and the precise location of these units is currently an area of intense research interest.

\section{Composition and Sites of Formation of Erythroblastic Islands}

Erythroblastic islands have been demonstrated in vivo in the fetal liver, bone marrow, and splenic red pulp, all sites of mammalian definitive erythropoiesis, as well as in long-term bone marrow cultures in vitro (Allen and Dexter, 1982). Thus, erythroblastic islands are essential for the maturation of erythroblasts that are destined to enucleate. Mature avian 
RBCs do not enucleate and differentiate in bone marrow that does not contain islands. It is unclear if primitive erythroblastic islands exist or whether primitive erythroblasts are nomads migrating to the flourishing community of definitive erythroblastic islands for assistance in their terminal stages of maturation. Erythroblastic islands have not been demonstrated in the yolk sac and should not be confused with yolk sac blood islands, which have long been recognized to be the first site for blood cell emergence during embryonic development (Ferkowicz and Yoder, 2005). These blood islands are a cluster of primitive erythroblasts surrounded by an endothelial covering and nestled between the outer visceral endoderm and inner mesothelial cell layers comprising the yolk sac. These cells arise from a common precursor called the hemangioblast that exists at the primitive streak, followed by the migration of committed progenitors to the proximal yolk sac. Further evidence for this model is provided by the emergence of the first wave of embryonic hematopoiesis well before any morphological indication of blood island development. While this may have no relevance to the subject at hand, it does raise parallel questions for the erythroblastic island such as: Do the erythroblastic cells and macrophage arise from a common precursor, and if so where does this precursor reside and what inductive signals are responsible for the assembly of the erythroblastic island? Is the island a true colony and do the macrophage and erythroblasts arise from the same cell, for example a granulocyte-erythroid-macrophagemonocyte (GEMM) precursor or even more speculative, a dedicated erythroid-macrophage precursor? Support for this possibility is provided by recent studies revealing the presence of primitive megakaryocyte-erythroid progenitors that give rise to yolk sac-derived megakaryocytes in addition to the previously identified primitive erythroid cells (Tober $e t$ al., 2007). Whether the primitive megakaryocyte-erythroid progenitors derive from primitive GEMM progenitors has not been investigated and needs to be studied specifically.

\subsection{Localization of erythroblastic islands within the bone marrow}

Erythroblastic islands are uniformly distributed throughout the bone marrow (Mohandas and Prenant, 1978). In order to demonstrate their presence and study their spatial distribution, Mohandas and Prenant performed a three-dimensional reconstruction of rat bone marrow based on $0.5 \mu \mathrm{M}$ serial sections (Fig. 2.1). These sections were stained and studied by light and electron microscopy. They were also photographed and the individual photographs were transferred to plastic sheets that were stacked to provide the three-dimensional distribution within the bone marrow. This formed the basis of a model built with cork balls scaled to the size of the cells and flat sheets of cork cut out to represent the sinusoids. A similar model was constructed for both normal and hypertransfused animals.

It was speculated that the erythroblastic islands would be most abundant adjacent to the sinusoids, allowing for the egress of reticulocytes into the vasculature. However, the equal predominance of islands in other locations led to the question of whether islands migrate toward the sinusoids as they mature. Quantitative light and electron microscopy of rat bone marrow did indeed show a difference in the composition of islands adjacent and nonadjacent to the sinusoids. Nonadjacent islands contain more proerythroblasts, and adjacent islands are rich in orthochromatophilic erythroblasts, the numbers of basophilic and polychromatophilic erythroblasts being comparable in both (Yokoyama et al., 2003). This remarkable finding suggests a migration of islands to the sinusoids as the cells within the island become more mature. Confirmation of such observations might uncover the role of proteases, secreted either by the mature erythroblasts or by central macrophage, that remodel underlying extracellular matrix making movement possible.

\subsection{Structure of erythroblastic islands}

Erythroblastic islands, consisting of a central macrophage surrounded by a ring of developing erythroblasts (Fig. 2.2 Bernard, 1991), had not been described prior to the 
pioneering studies by Marcel Bessis. The reason for this is that they are easily disrupted when bone marrow smears are prepared for examination. However, Bessis found that "it is fairly easy to see the erythroblastic island in the living state in phase-contrast microscopy. To do so, one need only remove, very carefully, a very small fragment of bone marrow from a freshly opened bone and dissociate it in a drop of plasma. In the resulting preparations, which admittedly are not very fine, the crown of erythroblasts surrounding the reticular cell is clearly visible." Howard Mel, one of Bessis' students, was the first to accomplish this task while spending a sabbatical year in Bessis' laboratory in 1970. He used an apparatus that permitted live cells to be isolated simply by the action of gravity. Following this, Le Charpentier isolated and examined these structures by treating the bone marrow with gentle physical or enzymatic disruption (Le Charpentier and Prenant, 1975), and techniques based on similar principles are currently in use (Crocker and Gordon, 1985; Lee et al., 2006; Sadahira et al., 1990). Erythroblastic islands can also be reconstituted when erythroblasts are coincubated with macrophage cells (Fig. 2.3; Iavarone et al., 2004; Lee et al., 2006) and isolated islands can also be maintained in culture (Hanspal et al., 1998; Le Charpentier and Prenant, 1975). The establishment of these techniques has been critical for the advancement in our understanding of the biological mechanisms governing the erythroblastic islands.

In steady-state erythropoiesis, erythroblastic islands are composed of erythroid cells in various stages of differentiation, ranging from CFU-E to young reticulocytes (Bessis et al., 1978; Le Charpentier and Prenant, 1975; Lee et al., 1988; Sadahira et al., 1999; Yokoyama et al., 2002). There is variation in the number of erythroblasts per island. Tissue sections from rat femur reveal about 10 cells per island (Yokoyama et al., 2002) whereas islands harvested from human bone marrow contain 5-30 erythroblasts per island (Lee et al., 1988).

Scanning electron microscopy of these islands shows cytoplasmic extensions arising from the macrophage that surround peripheral erythroid cells providing intimate contact between the macrophage and the developing erythroblasts (Fig. 2.4; Allen and Dexter, 1982). The formation and integrity of this island structure involves multiple adhesive interactions between adjacent erythroblasts and between cells of the island and the extracellular matrix (Arkin et al., 1991; Armeanu et al., 1995; Coulombel et al., 1991; El Nemer et al., 1998; Kansas et al., 1990; Rosemblatt et al., 1991).

\subsection{Unique immunophenotypic signature of the central macrophage}

The central macrophage arises from a resident monocyte precursor. Mouse central macrophages can be distinguished from other stromal cells in hematopoietic tissues by the expression of F4/80 antigen and Forssman glycosphingolipid. F4/80 is a cell surface glycoprotein with homology to the G-protein-linked transmembrane 7-hormone receptor family (Austyn and Gordon, 1981; Hirsch et al., 1981; Hume and Gordon, 1983; Hume et al., 1983; McKnight et al., 1996). In early studies by Crocker and Gordon (1985), macrophages were isolated from hematopoietic cell clusters in mouse bone marrow (Fig. 2.5). These were closely compared to resident macrophages from the peritoneal cavity and to circulating monocytes (Table 2.1). The erythroblastic island macrophages are very large with diameters frequently exceeding $15 \mu \mathrm{m}$ and have a nuclear/cytoplasmic ratio of much less than 1 . These cells were intensely F4/80 avid and possessed delicate plasma membrane processes. The elaborately branched processes appear to cradle the attached hematopoietic cells (Fig. 2.5C). The F4/80 weakly stained cells were comparatively smaller, rounded, and without plasma membrane extensions. They resembled promonocytes and monocytes with a reniform nuclei and a nuclear/cytoplasmic ratio greater than 1 . Resident bone marrow and peritoneal macrophages were similar in that both stained uniformly with F4/80 and 2.4G2 (IgG1/2b FcR), although the intensity of staining for both antigens was considerably greater in the resident bone marrow macrophages. In contrast to peritoneal macrophages however, resident bone marrow macrophages had no detectable Mac-I antigen expression, the 
presumed ligand-binding site of C3. Complement receptors were readily identified on peritoneal macrophages, monocytes, and neutrophils. The central macrophages showed high phagocytic activity and absence of a respiratory burst with a potent stimulator. They bound strongly to unopsonized sheep erythrocytes. In addition, the cells that the central macrophages associated with were actively cycling, suggesting their trophic roles as opposed to simply being scavengers of dead cells. With their pronounced adhesive properties and ability for avid endocytosis, they are perfectly adapted to function as nurse cells. The lack of respiratory burst and the consequent release of toxic oxidative species are perhaps protective to the surrounding erythroblasts. Macrophages obtained from splenic (Sadahira et al., 1990, 2000) and hepatic erythroblastic islands (Naito et al., 1997) share a similar profile to bone marrow-derived central macrophages. In contrast, the monocytes and peritoneal macrophages with their complement receptors and respiratory burst activity play an important role in inflammatory states.

Forssman glycosphingolipid distinguishes central macrophages from monocytes and inflammatory macrophages in hematopoietic tissues (Sadahira et al., 1988). This antigenhas a structure of GalNAc $\alpha 1-3 \mathrm{GalNAc} \beta 1-3 \mathrm{Gal} \alpha 1-4 \mathrm{Gal} \beta 1-4 \mathrm{Glc} \beta 1-\mathrm{Cer}$ and is synthesized by glycoside $\alpha 1-1,3-N$-acetylgalactosaminyl-transferase (Haslam and Baenziger, 1996). Using a combination of F4/80 and Forssman GSL, hematopoietic tissue macrophages can be classified as F4/80+Forssman- (immature) and F4/80+Forssman+(mature) subpopulations. Using allogeneic bone marrow transplantation, Forssman GSL was not expressed in macrophages soon after lodgment in hematopoietic tissues but was expressed as they matured in the tissues (Sadahira et al., 1991). Human bone marrow-derived central macrophages also express FcRI, FcRII, FcRIII, CD4, CD31, CD11a, CD 11c, CD 18, CD 31, and HLA-DR.

\subsection{Enucleation of primitive and definitive erythrocytes}

It was recognized more than 125 years ago that the mature RBCs of adult vertebrates circulate either in nucleated or in enucleated forms. RBCs of birds, fish, reptiles, and amphibians retain their nucleus and contain three filamentous systems: an actin-spectrinbased cytoskeleton, intermediate filaments that attach the cytoskeleton to the nuclear membrane, and a group of microtubules organized into a circumferential marginal band (Cohen, 1991). In contrast, the definitive RBCs of mammals lose intermediate filaments and microtubules during terminal differentiation and enucleate prior to entering the bloodstream; that is, the cells mature extra-vascularly. Enucleation of definitive erythrocytes is accompanied by several cell divisions and a progression of morphologically identifiable forms, resulting from the accumulation of hemoglobin in the cytoplasm and condensation of the nucleus. The loss of the intermediate filaments allows the nucleus to move freely to the periphery of the cell and occupy an acentric position prior to enucleation. A number of studies have proposed that enucleation may be a process similar to cytokinesis (Campbell, 1968; Repasky and Eckert, 1981a,b,c; Simpson and Kling, 1967; Skutelsky and Danon, 1967,1970 ) and have suggested that F-actin is present in the form of a ring in the constriction, similar to the cleavage furrow of mitotic cells (Perry et al., 1971; Schroeder, 1973). Using splenic erythroblasts from mice infected with the anemia-inducing strain of Friend virus, Koury et al. (1989) showed that F-actin is concentrated between the extruding nucleus and incipient reticulocyte in enucleating erythroblasts. The combination of the cleavage furrow formed by coalescing vacuoles with new membranes and the constriction of the actin ring results in the nucleus being pinched off with a thin rim of cytoplasm and the surrounding plasma membrane from the incipient reticulocyte. The disruption of F-actin bundles with cytochalasin D treatment inhibits enucleation (Koury et al., 1988), while Emp, B1-integrin, and glycoconjugates are recognized by concanavalin A partition to the nucleus (Geiduschek and Singer, 1979; Koury et al., 1989; Lee et al., 2004). The furrow also 
contains several mitochondria, which are also seen in a similar location during cytokinesis, supporting the concept that erythroid enucleation is a specialized form of cell division. The process of enucleation involves segregation of cytoskeletal and cell surface proteins between the plasma membrane of the nucleus and the incipient reticulocyte. Most of the major cytoskeletal proteins including band 3, spectrin, ankyrin, and 4.1 protein segregate to the newly formed reticulocyte. The processes described above occur within the definitive erythroblastic islands, allowing the central macrophage easy access to the expelled nucleus for phagocytosis and digestion. Ongoing studies suggest that the disproportionately greater segregation of adhesive receptors to the cytoplasmic membrane surrounding the expelled nucleus (Lee et al., 2004) favors its engulfment by the macrophage and the reciprocal decrease in adhesive proteins on the newly formed reticulocyte, its separation from the nurse cell.

The long-standing perception had been that primitive mammalian erythrocytes retain their nuclei and are thus more similar to avian, fish, and reptile RBCs. However, Kingsley et al. (2004) have shown that primitive erythroblasts progressively enucleate in circulation between embryonic day 12.5 (E12.5) and E16.5. Using antibodies to specific regions of murine embryonic $\beta \mathrm{H} 1$-globin and adult $\beta$ major-globin, they were able to differentiate yolk sac-derived primitive RBCs. These antibodies, in combination with nuclear staining, identified three distinct populations in the peripheral blood of E13.5-E15.5 fetusesnucleated primitive erythroblasts, enucleated primitive erythrocytes that express $\beta \mathrm{H} 1$-globin, and the definitive cells that are enucleated and express $\beta$ major-globin. There are a number of similarities in the erythropoietic program of primitive and definitive cells; for one, in both programs there is progressive maturation with enucleation (De la Chapelle et al., 1969; Steiner and Vogel, 1973). In addition, prior to enucleation, the cells lose intermediate filaments (Sangiorgi et al., 1990) and the nuclei condense and move to the plasma membrane. Despite these similarities, the one remarkable difference is that there is no evidence yet that the primitive erythroblasts require contact with macrophages to enucleate. Does this occur while the cells are in circulation and if so, what are the unique molecular mechanisms that govern enucleation in these cells? One might alternately speculate that the primitive erythroblasts migrate to sites, for instance, in the fetal liver, where reticuloendothelial cells play the role of the macrophage "nurse" cells.

\section{Cell-Cell Adhesive Interactions Within Erythroblastic Islands}

A number of cell adhesion molecules and their interactions within the erythroblastic islands have been described and have been proven to be critical for island integrity. The precise role of these adhesive interactions is still unclear. Given that the integrin-actin cytoskeleton interactions regulate intracellular signaling, they may coordinate adhesion and gene expression in the erythroblastic islands (Table 2.2).

\subsection{Erythroblast macrophage protein}

Erythroblast macrophage protein is a $36-\mathrm{kD}$ transmembrane protein expressed on the surface of both erythroblasts and macrophages (Hanspal et al., 1998). The cytoplasmic domain contains several binding sites for SH2 domains and a potential binding site for phosphotyrosine-binding domains, suggesting a signaling function. Erythroblasts cultured in the presence of anti-Emp show the same phenotype as those cultured in the absence of macrophages - a sixfold increase in apoptosis is observed, accompanied by a marked decrease in erythroid proliferation, maturation, and enucleation (Hanspal et al., 1998). Furthermore, Emp-null murine fetuses are severely anemic and die in utero at E19.5, that is perinatally, strongly supporting a crucial role for Emp in definitive erythropoiesis (Soni et al., 2006). Emp-null fetal liver macrophages exhibit both a quantitative and a qualitative defect. The number of F4/80 positive cells is reduced to $25-30 \%$ of wild-type values and in 
appearance they are smaller, round in shape, and lack cytoplasmic extensions, suggesting an immature morphology. Consistent with this, ER-MP12, an antigen expressed by immature macrophage precursors, is expressed normally. This suggests that loss of Emp impairs terminal maturation but not commitment to macrophage lineage. In vitro erythroblast reconstitution assays using Emp-null erythroblasts or Emp-null macrophages with their wild-type counterparts indicate that Emp function is both RBC and macrophage autonomous. Interestingly, recent studies using transfected mammalian cells showed that Emp is localized in the contractile ring during cytokinesis and that it exists in a complex with actin in vivo (Bala et al., 2006). Immunofluorescent labeling of wild-type and mutant erythroblasts with phalloidin detected a striking difference in the localization pattern of Factin: in the wild-type erythroblasts, actin staining, which completely colocalized with Emp staining, was present throughout the cytoplasm as well as on the plasma membrane. In the mutant erythroblasts, however, actin staining was detected largely near the plasma membrane. Almost no cytoplasmic actin was detected in mutant cells, suggesting that in the absence of Emp, the actin distribution is impaired in erythroblasts. Emp also colocalizes with concentrated F-actin bundles that are detected in wild-type erythroblasts undergoing enucleation. Thus, in addition to being involved in nuclear expulsion, Emp-actin association may function to regulate the actin cytoskeleton in reticulocytes.

The potential role of Emp in regulating actin cytoskeleton has implications in macrophage function as well. Emp-deficient macrophages display condensed, less organized actin filaments, and are therefore unable to efficiently develop long cytoplasmic extensions. Detailed characterization of Emp-null macrophages in terms of their capacity to migrate, invade, and phagocytose, all of which are actin-based cellular events, will shed further light on these processes.

\section{2. $\alpha 4 \beta 1$ (vla-4)/VCAM-1}

Adhesive interactions occur between $\alpha 4 \beta 1$ integrin expressed on erythroblasts and its counter-receptor-vascular adhesion molecule-1 (VCAM-1) expressed on macrophage cells. Monoclonal antibodies to either receptor disrupt island integrity in vitro (Sadahira $e t$ al., 1995). Treatment of mice with very late antigen-4 antibodies in utero specifically induces anemia (Hamamura et al., 1996).

\subsection{Intercellular adhesion molecule-4/av}

The erythroid-specific isoform ofintercellularadhesionmolecule-4 (ICAM-4) expressed on erythroid cells (LW blood group glycoprotein, CD 242) interacts with $\alpha \mathrm{v}$ integrin on macrophage cells (Spring et al., 2001) as well as the leukocyte $\beta 1$ integrin and platelet integrin $\alpha \mathrm{II} \beta 3$ (Telen, 2005). Blocking ICAM-4- $\alpha \mathrm{v}$ binding with $\alpha \mathrm{v}$ synthetic peptides produces a $70 \%$ decrease in islands reconstituted in vitro (Lee et al., 2006). ICAM-4-null mice have a $50 \%$ decrease in island formation in the bone marrow; however, steady-state erythropoiesis is not adversely affected in the adult animal. A secreted isoform of mouse ICAM-4, ICAM-4S, that is upregulated in terminal differentiation has been described. ICAM-4S may compete with membrane-bound integrin counter-receptors, thereby blocking the interaction of ICAM- 4 with $\alpha \mathrm{v}$. This might facilitate the detachment of young reticulocytes from the islands, thereby enabling their egress into the vasculature.

Three other macrophage receptors that could be involved in adhesion to erythroblasts include lectin-like sheep erythrocyte receptor (Crocker and Gordon, 1985, 1986; Crocker $e t$ al., 1990), erythroblast receptor (EbR), and ED2 antigen (Barbe et al., 1996). Neither these receptors nor their corresponding ligands have been fully characterized. 
A recent study shows palladin, an actin cytoskeleton-associated protein, is an important regulator of fetal liver definitive erythropoiesis (Liu et al., 2007). Its disruption results in significant fetal anemia caused by impaired fetal liver definitive erythropoiesis resulting from disrupted erythroblastic island formation, suggesting a role for paladin in cell-cell interaction. The mutant HSCs in fetal liver can reconstitute lethally irradiated mice and differentiate into different lineages in methylcellulose culture system. These results suggest that palladin may regulate definitive erythropoiesis through a noncell autonomous manner. Erythroblastic island reconstitution assays show that intrinsic defects in palladin-/macrophages but not erythroblasts are responsible for impaired erythroblastic island formation, and consequently definitive erythropoiesis deficiency. Many known adhesive proteins were characterized within the palladin-null islands and were found to be unaffected, further underscoring the possibility of novel adhesive pathways operant within the erythroblastic islands (Liu et al., 2007).

\section{Erythroblastic Island Functions}

Erythroblasts can proliferate, mature, and enucleate in vitro in the absence of other cell types; however, this process is typically very inefficient at all stages (Hanspal et al., 1998) and strikingly only a minority of in vitro differentiated erythroblasts complete the final step of enucleation. The generation of fully mature, enucleated erythrocytes is enhanced by the coculture with macrophages (Qiu et al., 1995) or other accessory cells such as murine stromal cell lines or human mesenchymal cells (Giarratana et al., 2005). The interaction of cells within the erythroblastic island is essential for both early and late stages of erythroid maturation. It has been proposed that early in erythroid maturation, the macrophages provide nutrients, and proliferative and survival signals to the erythroblasts. It has long been recognized that macrophages phagocytose extruded erythroblast nuclei at the conclusion of erythroid maturation. There is also accumulating evidence for the role of macrophages in promoting enucleation itself. Furthermore, macrophages provide adhesive interactions that maintain island integrity. The role of the adhesive interactions has yet to be clearly delineated-it is likely that they allow for regulatory feedback within islands via cross talk between cells and also trigger intracellular signaling pathways that regulate gene expression

\subsection{Positive and negative growth regulatory effects on developing erythroblasts within the erythroblastic island}

The concept of a control mechanism for cellular growth through modulation of apoptosis has recently come to include a wide variety of tissue systems, including hematopoietic cells. Changes in the balance between cell survival and death are clear signs of development of hematologic disorders such as the myelodysplastic syndromes (Greenberg, 1998; Parker and Mufti, 1998) and chronic myelogenous leukemia (Clarkson et al., 1997). Therefore, tight regulation of apoptosis is needed to maintain hematopoietic homeostasis. The apoptosis of hematopoietic progenitor cells is regulated both positively and negatively by an interacting network of various cytokines and adhesive molecules (Wickremasinghe and Hoffbrand, 1999). It is therefore not surprising that such mechanisms are operant within the erythroblastic island.

Macrophages secrete cytokines that promote erythroblast proliferation and maturation. These include burst-promoting activity and insulin-like growth factor-1 (Kurtz et al., 1985; Sawada et al., 1989), factors that can stimulate the growth of BFU-E and CFU-E. Although erythropoietin mRNA expression has been demonstrated in mouse bone marrow macrophages (Rich et al., 1988a,b), the precise role of macrophages in either synthesizing erythropoietin or presenting erythropoietin synthesized elsewhere remains to be elucidated. It has, however, been shown that coculture of erythroblasts with macrophages prevents erythroblast apoptosis (Hanspal et al., 1998). 
Erythroblasts express Fas throughout differentiation; however, only immature erythroblasts are susceptible to the death signal resulting from Fas/Fas ligand cross-linking. Late differentiating erythroblasts exhibit a Fas-based cytotoxicity against the immature erythroblasts via Fas ligand induction (De Maria et al., 1999). It has been speculated that high levels of erythropoietin within the island protect the immature erythroblasts from this signaling pathway, promoting increased erythroid survival. This mechanism would upregulate erythropoiesis in anemic individuals that exhibit increased erythropoietin levels. Besides a negative feedback loop between mature and immature erythroblasts, there is one described between macrophages and immature erythroblasts that involves RCAS1 (receptor binding cancer antigen expressed in Siso cells) and its receptor (Matsushima et al., 2001). Immature erythroblasts express RCAS1 receptor. Soluble RCAS1, secreted by bone marrow macrophages, activates proapoptotic caspases- 8 and -3 in immature erythroblasts. These observations indicate that during erythropoiesis the level of apoptotic cell death is finely modulated in the erythroblastic islands by positive and negative regulatory factors, mainly at specific stages of cellular maturation that are predominantly at a high proliferative capacity.

\subsection{The role of macrophages in supplying iron for hemoglobin synthesis}

Another important unanswered question is whether macrophages supply iron for hemoglobin synthesis as was originally thought. In 1962, Bessis reported that in humans (but not rats or mice), ferritin molecules always occur in the space between erythroblasts and the histiocyte cell membrane and/or attached to the erythroblast membrane. It is unclear what the source of the ferritin is, whether it is derived from plasma or from the central histiocyte that extrudes it when it is in contact with an erythroblast. Whatever the origin of the ferritin, it is incorporated into the erythroblast by "rhopheocytosis," a process now known to be micropinocytosis (Policard and Bessis, 1962). These vesicles are filled with ferritin and form as a result of invagination of the surface membrane to which ferritin is attached utilizing a specific acid ferritin receptor (Konijn et al., 1994). The vesicles disappear in the interior of the cytoplasm and the ferritin molecules are liberated. Over the last 10 years, our understanding of mammalian iron transport and homeostasis has advanced dramatically and it is likely that these questions will be addressed in the near future in a more meaningful manner. We now know some of the key players in iron homeostasis, such as hepcidin, a circulating peptide hormone primarily produced by hepatocytes (Nicolas $e t$ al., 2001; Park et al., 2001; Pigeon et al., 2001) and ferroportin, the major transmembrane transporter transferring iron out of enterocytes, macrophages, and, to a lesser extent, hepatocytes (Abboud and Haile, 2000; Donovan et al., 2005; Fraenkel et al., 2005) (1316Nar). Studies in cultured cells have established that that hepcidin binds directly to ferroportin, triggering its internalization and degradation within lysosomes (Nemeth et al., 2004). Hepcidin expression is altered in response to each of the stimuli known to affect iron homeostasis: in conditions of stress erythropoiesis, for example in hypoxia or iron deficiency anemia, levels of hepcidin are decreased resulting in decreased ferroportin inactivation (Andrews and Schmidt, 2006). While the increase in ferroportin at the basilar surface of enterocytes results in increased absorption of dietary iron to provide additional substrate in face of an increased demand, it is intriguing to speculate that the ferroportin on the surface of central macrophages is also upregulated. This could result in local export of iron to the erythroblasts within the island.

\subsection{Engulfment and breakdown of extruded nuclei play an important role in the regulation of late stage erythropoiesis}

It has been shown by time lapse videography that the macrophages actively phagocytose extruded definitive erythroblast nuclei at the end of terminal differentiation (reviewed by Bessis et al., 1978). This macrophage function has been documented in vitro in long-term bone marrow cultures (Allen and Dexter, 1982) and in vivo in mice lacking DNase II, where 
fetal liver macrophages become engorged with multiple ingested, but not digested, nuclei (Kawane et al., 2001). It has further been demonstrated that the macrophage function of engulfment and digestion of extruded nuclei is vital for continued erythropoiesis. In the mice lacking DNase II, the lack of nuclear digestion resulted in a severe defect in erythropoiesis and embryonic lethal anemia (Yoshida et al., 2005b). DNase II is an endonuclease present in the lysosomes of macrophages that cleaves DNA after macrophages engulf apoptotic cells or the nuclei that are expelled from erythroid precursor cells. Yoshida et al. have shown that the gene encoding IFN- $\beta$ (Ifnb1) was activated in DNase II-/- fetal liver and that lack of signals from the interferon type I receptor "rescued" the anemia and the lethality.

DNase II-/- embryos produced not only IFN- $\beta$ but also IFN $-\gamma$. But, in contrast to IFN- $\beta$, IFN- $\gamma$ had little cytotoxic effect on erythroid cells. RNA hybridization analysis indicated that Ifnb1 was activated in DNase II-/- fetal liver, but expression was low and no interferon activity was detected in the serum of the embryos. In contrast, in situ hybridization detected IFN $-\beta$ mRNA in the macrophages carrying undigested DNA in the blood islands of DNase II- - - fetal liver. The authors concluded that IFN $-\beta$ produced in the fetal liver is responsible for inhibiting erythropoiesis that occurs in association with macrophages at the blood islands. Many cytokines have more potent activity in a membrane-associated form than in a soluble form. It is likely that IFN- $\beta$ expression by macrophages in the blood islands, even in low concentrations, has a deleterious effect on erythropoiesis.

Analysis of erythroblast plasma membrane protein (Emp) that partitions between the nucleus, as it is being expelled, and the reticulocyte shows that Emp partitions predominantly to the plasma membrane surrounding the extruded nucleus (Lee et al., 2004). This process would result in effective macrophage binding at the site, thereby facilitating phagocytosis. Furthermore, the extruded nuclei contain markedly decreased ATP and increased calcium (Yoshida et al., 2005a). It has been speculated that these alterations inactivate the aminotranslocase and activate the scramblase, resulting in movement of the phosphatidylserine from the inner to the outer leaflet of the lipid bilayer. This rapid exposure of phosphatidylserine and engulfment of the nuclei by macrophages has been demonstrated in vitro (Yoshida et al., 2005a). Furthermore, engulfment of nuclei is blocked by a dominant negative mutant of milk fat globule epidermal growth factor EGF-8, known to inhibit phagocytosis of apoptotic cells by blocking surface phosphatidylserine (Hanayama et al., 2002).

The defect of severe anemia and in utero death in late gestation seen in DNase II-null mice is recapitulated in one of the three phosphatidylserine receptor knockout mouse models (Kunisaki et al., 2004) that presumably leads to the inability of macrophage cells to ingest extruded nuclei. The conserved mitogen-activated protein kinase family members c-Jun Nterminal kinase ( JNK) and p38 have been implicated in stress and proinflammatory signal transduction and recently in erythropoiesis. Homozygous deletion of either JNK1 or JNK2 in mice has no apparent effect on hematopoiesis (Bonnesen et al., 2005), which might be explained by redundancy between the JNK isoforms. In contrast, the Jnk1-/- Jnk2-/embryos die early in embryonic development (E11.5-12.5) due to dysregulation of apoptosis in brain development, making the contribution of the JNK in definitive erythropoiesis in vivo difficult to study further. Bonnesen et al. (2005) investigated the role of the JNKactivating kinase mitogen-activated protein kinase/extracellular signal to regulated kinase (MEK), kinase 1 (MEKK1), in development. Mice deficient in MEKK1 kinase activity (Mekk1KD mice) were generated and are alive and fertile on a C57/BL6×129 background. Unexpectedly, after backcrossing the Mekk1 KD/+ heterozygotes into the C57/BL6 background, a dramatic decrease in the frequency of live Mekk1KD embryos that develop past E14.5 was observed. At E14.5, all mutant embryos studied, although morphologically normal, were anemic and showed defective definitive erythropoiesis with accumulation of 
nucleated late erythroblasts. These studies strongly suggest that MEKK1-JNK signaling is required for degradation of nuclear DNA extruded from erythroid precursors during the late stages of definitive erythropoiesis in the fetal liver. Crossing the Mekk1KD/+ C57/BL/ $6 \times 129$ hybrids with Jnk1-/- or Jnk2-/- mice resulted in embryonic lethality of all Mekk1KD Jnk1-/- and Mekk1KD Jnk2-/- embryos (regardless of background), suggesting that an intact MEKK1-JNK signaling pathway is required for normal embryonic development. Mekk1KD, Mekk1KD Jnk1-/-, and Mekk1KD Jnk2-/- embryos have identical phenotypes, survive up to midgestation, and display normal morphology but are highly anemic. Interestingly, a similar phenotype has been observed in p38-deficient mice. However, while the anemia in p38-/- mice is attributed to defective erythropoietin gene expression, normal levels of erythropoietin at both mRNA and protein level were observed in Mekk1KD and Mekk1KD Jnk2-/- embryos. The fetal livers of Mekk1KD and Mekk1KD Jnk2-/- also contain BFU-Es and CFU-Es formed at normal frequencies, and can reconstitute erythropoiesis in lethally irradiated hosts. It is therefore clear that MEKK1 is not required for the production of, or the response to, cytokines and/or growth factors required for the expansion and differentiation of erythroid progenitors up to the stage where the orthochromatic erythroblasts lose their nuclei and become reticulocytes. The phenotype of these mice is almost identical to those lacking DNaseII (described above). However, fetal livers from Mekk1KD and Mekk1KD Jnk2-/- embryos contain reduced levels of macrophages and TUNEL stains showed extensive accumulation of apoptotic bodies. These apoptotic bodies did not colocalize with Ter119-positive erythroblasts but rather appeared free in the extracellular space, suggesting that they represent nuclear DNA extruded from erythroid precursor cells. The fetal liver macrophages from the mutant mice exhibit normal phagocytic function, implicating the decrease in the number of macrophages in the development of defective erythropoiesis.

All together these results suggest that engulfment and breakdown of extruded nuclei play an important role in the regulation of late stage erythropoiesis.

\subsection{Macrophages promote enucleation}

Another important question is whether the macrophages also promote enucleation or whether this is mediated via retinoblastoma tumor suppressor $(\mathrm{Rb})$ protein. $\mathrm{Rb}$ is present in the nucleus of all cells and plays a critical role in cell cycle decisions. Mice lacking Rb, in addition to other defects, have defective erythropoiesis and erythroblasts in the fetal liver that fail to mature and enucleate (Clarke et al., 1992; Jacks et al., 1992; Lee et al., 1992). It is yet unclear whether the role of $\mathrm{Rb}$ in $\mathrm{RBC}$ enucleation and maturation is intrinsic (Clark et al., 2004; Spike et al., 2007) to the RBCs or extrinsic to it (Iavarone et al., 2004; Palis, 2004).

When $\mathrm{Rb}$-deficient stem cells are transplanted into normal mice, the cells fail to enucleate and the animals are anemic. However, chimeric mice composed of both normal and mutant cells give rise to erythrocytes that are $\mathrm{Rb}-$ mutant in origin, raising the possibility that the $\mathrm{Rb}$ protein in macrophages may be essential for the process (Williams et al., 1994).

Evidence for this hypothesis is provided by Iavarone et al. (2004). They reported that these animals have a marked reduction of mature macrophages in the liver as well as the presence of immature macrophages that are unable to bind erythroblast. They suggest that the effects of $\mathrm{Rb}$ on macrophage maturation are mediated by Id2 and PU.1. Id2, a nuclear protein, is bound by $\mathrm{Rb}$. Id2 can bind to transcription factor PU.1, a critical regulator of genes expressed in macrophages, and this interaction inhibits the transcription of macrophage specific genes. The macrophage defect in Rb-deficient mice can be reversed by loss of Id2. Their results are consistent with a model in which $\mathrm{Rb}$ binds to Id 2 in the nucleus of immature macrophages, thus freeing PU.1 to transcribe genes involved in maturation of macrophages into erythroblast nursing cells, playing a critical role in RBC enucleation. In 
complete contrast to the studies described above, analysis of erythroblast maturation in vitro (Clark et al., 2004; Spike and Macleod, 2005) or in Rb-null chimeric mice that are challenged in vivo with phenylhydrazine to induce stress erythropoiesis recapitulates the erythroid maturation defects seen in the developing $\mathrm{Rb}$-null fetal liver, including the failure to enucleate and upregulate TER119 (Spike and Macleod, 2005), raising the possibility that $\mathrm{Rb}$ is required in a cell intrinsic manner to regulate erythropoiesis. This is specifically true under conditions of oxidative or proliferative stress. Spike et al. (2007) argue that it is unlikely that $\mathrm{Rb}$ plays a specific role in maintaining erythroblastic island integrity as was originally concluded from the examination Rb-null fetal livers. They suggest that the disruption in erythroblastic island formation is a direct result of hypoxia. To test this hypothesis, they counted the total number of erythroblastic islands and the number of erythroblasts per macrophage in cultures of native islands grown at either regular tissue culture or in hypoxic conditions. For these assays, they used fetal liver from control mice and conditionally targeted mice in which $\mathrm{Rb}$ was deleted in the embryo but not in the placenta (Wu et al., 2003) to control for differential effects of ischemia experienced in vivo. At $21 \%$ oxygen, they failed to observe any significant difference in numbers of islands or in erythroblasts per macrophage formed with Rb-deficient fetal liver cells relative to control. However, when they cultured fetal liver from controls or from Rb-deficient mice under hypoxic conditions, they observed a dramatic reduction in both the number of islands and the number of erythroblasts per macrophage suggesting that hypoxia, as opposed to $\mathrm{Rb}$ gene status, was instrumental in disrupting erythroblastic islands. Histological examination of fetal livers of $\mathrm{Rb}$-deficient mice revealed a preponderance of $\mathrm{F} 4 / 80$ positive macrophages adjacent to the ischemic areas, suggesting that macrophages in the Rb-null fetal liver may be diverted from their role in erythropoietic island formation to promote clearance of dying cells. Furthermore, they demonstrate the absence of any reduction in proportionate representation of F4/80-positive macrophages between wild-type and Rb-null fetal livers and a similar quality of erythroblastic islands in the intact proximal regions of the Rb-null fetal liver is similar to wild type. The same authors showed that when the erythroblastic islands were cultured, $\mathrm{Rb}$-null macrophages and wild-type macrophages were both competent to bind erythroblasts. They also used microarray data and quantitative real-time PCR to examine how loss of $\mathrm{Rb}$ affected expression of macrophage-specific genes that have been implicated in the erythroblastic island defect in Rb-null fetal livers, including c-Fms, myeloperoxidase, cathepsin S, complement components, and lysozyme. In contrast to the effect of $\mathrm{Rb}$ loss on hypoxia-inducible gene expression, they failed to detect any significant change in the expression levels of most macrophage-specific genes in Rb-null fetal liver relative to wild type at E12.5 (Spike et al., 2007). Expression of c-Fms (a PU1 target gene) was previously shown to be deregulated in Rb-null MEFs, and together with data implicating deregulated PU1 in erythroblastic island defects in Rb-null fetal liver was taken as evidence that macrophages were not functioning normally in Rb-null fetal liver (Iavarone et al., 2004). However, Spike et al. were unable to detect any reduction in c-Fms levels by quantitative real-time PCR in Rb-null fetal liver relative to wild type. While further studies will be required to resolve the role of $\mathrm{Rb}$ within macrophages, the observation that in vitro erythroid enucleation progresses more efficiently in the presence of stromal cells (Giarratana et al., 2005) and requires physical force (Yoshida et al., 2005a) further supports the possibility that tethering to macrophages facilitates enucleation.

\subsection{Erythroblasts within the island are a source of angiogenic factors that exert paracrine effects}

Erythroblasts secrete two angiogenic factors, vascular endothelial growth factor A (VEGFA) and placental growth factor (PIGF) (Tordjman et al., 2001). Media from cultured erythroblasts induces migration of monocytes and endothelial cell permeability, both inhibited by VEGF-A- and PIGF-A-specific antibodies. Erythroid progenitors do not express 
receptors for either of these angiogenic factors whereas central macrophages do, and thus the secreted molecules may have paracrine effects regulating island integrity. In addition, the angiogenic factors may enable egress of the reticulocytes into the vasculature by modulating endothelial cell junctional integrity.

\subsection{Erythroblast-mediated regulation of erythropoiesis via cell-cell interaction}

Erythroblast intercellular signaling seems to regulate the activity and gene expression of GATA-1, a transcription factor crucial for erythropoiesis. While the absence of GATA-1 results in proerythroblast apoptosis (Pevny et al., 1991, 1995; Weiss et al., 1994) and embryonic lethality in knockout mice (Fujiwara et al., 1996), its overexpression blocks terminal differentiation (Whyatt et al., 1997; Lindeboom et al., 2000). Strikingly, the presence of normally expressing cells enables overexpressing cells to complete terminal differentiation. Using a mouse model in which only half the RBCs overexpress GATA-1, it has been observed that the normal late stage erythroblasts produce a signal termed (RBC differentiation signal (REDS) that corrects the flaw in overexpressing cells (Gutierrez et al., 2004). Mechanistically this appears to involve cell-cell interaction rather than a soluble factor, underscoring the importance of island integrity in the execution of this regulatory function.

\section{Conclusion}

The biological significance of islands has frequently been questioned. Unraveling the processes that lead to effective erythropoiesis in these niches is in an early stage and future work will contribute to the understanding of the true relevance of this system to normal and pathological hematopoiesis in vivo.

\section{Acknowledgments}

Studies in the authors' laboratories have been supported by the National Institutes of Health (K08 DK02871, R01 DK46865, DK48721, and HL73437).

\section{References}

Abboud S, Haile DJ. A novel mammalian iron-regulated protein involved in intracellular iron metabolism. J Biol Chem. 2000; 275:19906-19912. [PubMed: 10747949]

Allen TD, Dexter TM. Ultrastructural aspects of erythropoietic differentiation in long-term bone marrow culture. Differentiation. 1982; 21:86-94. [PubMed: 7084572]

Andrews NC, Schmidt PJ. Iron homeostasis. Annu Rev Physiol. 2006; 69:69-85. [PubMed: 17014365]

Arkin S, Naprstek B, Guarini L, Ferrone S, Lipton JM. Expression of intercellular adhesion molecule-1 (CD54) on hematopoietic progenitors. Blood. 1991; 77:948-953. [PubMed: 1671649]

Armeanu S, Buhring HJ, Reuss-Borst M, Muller CA, Klein G. E-cadherin is functionally involved in the maturation of the erythroid lineage. J Cell Biol. 1995; 131:243-249. [PubMed: 7559781]

Austyn JM, Gordon S. F4/80, a monoclonal antibody directed specifically against the mouse macrophage. Eur J Immunol. 1981; 11:805-815. [PubMed: 7308288]

Axelrad, AA.; McLeod, DL.; Shreeve, MM.; Heath, DS. Properties of cells that produce erythrocytic colonies in vitro. In: Robinson, WA., editor. Hemopoiesis in Culture. DHEW publication; Washington, DC: 1974. p. 226

Bala S, Kumar A, Soni S, Sinha S, Hanspal M. Emp is a component of the nuclear matrix of mammalian cells and undergoes dynamic rearrangements during cell division. Biochem Biophys Res Commun. 2006; 342:1040-1048. [PubMed: 16510120]

Barbe E, Huitinga I, Dopp EA, Bauer J, Dijkstra CD. A novel bone marrow frozen section assay for studying hematopoietic interactions in situ: The role of stromal bone marrow macrophages in erythroblast binding. J Cell Sci. 1996; 109(Pt 12):2937-2945. [PubMed: 9013341] 
Bernard J. The erythroblastic island: Past and future. Blood Cells. 1991; 17:5-10. discussion 10-14. [PubMed: 2018860]

Bessis M. Erythroblastic island, functional unity of bone marrow. Rev Hematol. 1958; 13:8-11. [PubMed: 13555228]

Bessis M, Breton-Gorius J. The erythroblastic islet and the rhopheocytosis of ferritin in inflammation. Nouv Rev Fr Hematol. 1961; 1:569-582. [PubMed: 13868558]

Bessis MC, Breton-Gorius J. Iron metabolism in the bone marrow as seen by electron microscopy: A critical review. Blood. 1962; 19:635-663. [PubMed: 13868561]

Bessis M, Mize C, Prenant M. Erythropoiesis: Comparison of in vivo and in vitro amplification. Blood Cells. 1978; 4:155-174. [PubMed: 747769]

Bonnesen B, Orskov C, Rasmussen S, Holst PJ, Christensen JP, Eriksen KW, Qvortrup K, Odum N, Labuda T. MEK kinase 1 activity is required for definitive erythropoiesis in the mouse fetal liver. Blood. 2005; 106:3396-3404. [PubMed: 16081685]

Campbell FR. Nuclear elimination from the normoblast of fetal guinea pig liver as studied with electron microscopy and serial sectioning techniques. Anat Rec. 1968; 160:539-554. [PubMed: 4874448]

Clark AJ, Doyle KM, Humbert PO. Cell-intrinsic requirement for $\mathrm{pRb}$ in erythropoiesis. Blood. 2004; 104:1324-1326. [PubMed: 15155463]

Clarke AR, Maandag ER, van Roon M, van der Lugt NM, van der Valk M, Hooper ML, Berns A, te Riele H. Requirement for a functional Rb-1 gene in murine development. Nature. 1992; 359:328330. [PubMed: 1406937]

Clarkson BD, Strife A, Wisniewski D, Lambek C, Carpino N. New understanding of the pathogenesis of CML: A prototype of early neoplasia. Leukemia. 1997; 11:1404-1428. [PubMed: 9305592]

Cohen WD. The cytoskeletal system of nucleated erythrocytes. Int Rev Cytol. 1991; 130:37-84. [PubMed: 1778729]

Coulombel L, Vuillet-Gaugler MH, Leroy C, Rosemblatt M, Breton-Gorius J. Adhesive properties of human erythroblastic precursor cells. Blood Cells. 1991; 17:65-78. discussion 79-81. [PubMed: 2018862]

Crocker PR, Gordon S. Isolation and characterization of resident stromal macrophages and hematopoietic cell clusters from mouse bone marrow. J Exp Med. 1985; 162:993-1014. [PubMed: 4031789]

Crocker PR, Gordon S. Properties and distribution of a lectin-like hemagglutinin differentially expressed by murine stromal tissue macrophages. J Exp Med. 1986; 164:1862-1875. [PubMed: 3783087]

Crocker PR, Werb Z, Gordon S, Bainton DF. Ultrastructural localization of a macrophage-restricted sialic acid binding hemagglutinin, SER, in macrophage-hematopoietic cell clusters. Blood. 1990; 76:1131-1138. [PubMed: 2205308]

De la Chapelle A, Fantoni A, Marks PA. Differentiation of mammalian somatic cells: DNA and hemoglobin synthesis in fetal mouse yolk sac erythroid cells. Proc Natl Acad Sci USA. 1969; 63:812-819. [PubMed: 5259765]

De Maria R, Testa U, Luchetti L, Zeuner A, Stassi G, Pelosi E, Riccioni R, Felli N, Samoggia P, Peschle C. Apoptotic role of Fas/Fas ligand system in the regulation of erythropoiesis. Blood. 1999; 93:796-803. [PubMed: 9920828]

Donovan A, Lima CA, Pinkus JL, Pinkus GS, Zon LI, Robine S, Andrews NC. The iron exporter ferroportin/Slc40a1 is essential for iron homeostasis. Cell Metab. 2005; 1:191-200. [PubMed: 16054062]

El Nemer W, Gane P, Colin Y, Bony V, Rahuel C, Galacteros F, Cartron JP, Le Van Kim C. The Lutheran blood group glycoproteins, the erythroid receptors for laminin, are adhesion molecules. $\mathrm{J}$ Biol Chem. 1998; 273:16686-16693. [PubMed: 9642222]

Emerson SG, Sieff CA, Wang EA, Wong GG, Clark SC, Nathan DG. Purification of fetal hematopoietic progenitors and demonstration of recombinant multipotential colony-stimulating activity. J Clin Invest. 1985; 76:1286-1290. [PubMed: 3876355]

Ferkowicz MJ, Yoder MC. Blood island formation: Longstanding observations and modern interpretations. Exp Hematol. 2005; 33:1041-1047. [PubMed: 16140152] 
Fraenkel PG, Traver D, Donovan A, Zahrieh D, Zon LI. Ferroportin1 is required for normal iron cycling in zebrafish. J Clin Invest. 2005; 115:1532-1541. [PubMed: 15902304]

Fraser ST, Isern J, Baron MH. Maturation and enucleation of primitive erythroblasts during mouse embryogenesis is accompanied by changes in cell-surface antigen expression. Blood. 2007; 109:343-352. [PubMed: 16940424]

Fujiwara Y, Browne CP, Cunniff K, Goff SC, Orkin SH. Arrested development of embryonic red cell precursors in mouse embryos lacking transcription factor GATA-1. Proc Natl Acad Sci USA. 1996; 93:12355-12358. [PubMed: 8901585]

Geiduschek JB, Singer SJ. Molecular changes in the membranes of mouse erythroid cells accompanying differentiation. Cell. 1979; 16:149-163. [PubMed: 421269]

Giarratana MC, Kobari L, Lapillonne H, Chalmers D, Kiger L, Cynober T, Marden MC, Wajcman H, Douay L. Ex vivo generation of fully mature human red blood cells from hematopoietic stem cells. Nat Biotechnol. 2005; 23:69-74. [PubMed: 15619619]

Gifford SC, Derganc J, Shevkoplyas SS, Yoshida T, Bitensky MW. A detailed study of timedependent changes in human red blood cells: From reticulocyte maturation to erythrocyte senescence. Br J Haematol. 2006; 135:395-404. [PubMed: 16989660]

Granick S, Levere RD. Heme synthesis in erythroid cells. Prog Hematol. 1964; 27:1-47. [PubMed: 14272797]

Greenberg PL. Apoptosis and its role in the myelodysplastic syndromes: Implications for disease natural history and treatment. Leuk Res. 1998; 22:1123-1136. [PubMed: 9922076]

Gutierrez L, Lindeboom F, Langeveld A, Grosveld F, Philipsen S, Whyatt D. Homotypic signalling regulates Gata1 activity in the erythroblastic island. Development. 2004; 131:3183-3193. [PubMed: 15175249]

Hamamura K, Matsuda H, Takeuchi Y, Habu S, Yagita H, Okumura K. A critical role of VLA-4 in erythropoiesis in vivo. Blood. 1996; 87:2513-2517. [PubMed: 8630418]

Hanayama R, Tanaka M, Miwa K, Shinohara A, Iwamatsu A, Nagata S. Identification of a factor that links apoptotic cells to phagocytes. Nature. 2002; 417:182-187. [PubMed: 12000961]

Hanspal M, Smockova Y, Uong Q. Molecular identification and functional characterization of a novel protein that mediates the attachment of erythroblasts to macrophages. Blood. 1998; 92:2940-2950 [PubMed: 9763581]

Haslam DB, Baenziger JU. Expression cloning of Forssman glycolipid synthetase: A novel member of the histo-blood group ABO gene family. Proc Natl Acad Sci USA. 1996; 93:10697-10702. [PubMed: 8855242]

Hirsch S, Austyn JM, Gordon S. Expression of the macrophage-specific antigen F4/80 during differentiation of mouse bone marrow cells in culture. J Exp Med. 1981; 154:713-725. [PubMed: 7276827]

Hume DA, Gordon S. Mononuclear phagocyte system of the mouse defined by immunohistochemical localization of antigen F4/80. Identification of resident macrophages in renal medullary and cortical interstitium and the juxtaglomerular complex. J Exp Med. 1983; 157:1704-1709. [PubMed: 6854206]

Hume DA, Robinson AP, MacPherson GG, Gordon S. The mononuclear phagocyte system of the mouse defined by immunohistochemical localization of antigen F4/80. Relationship between macrophages, Langerhans cells, reticular cells, and dendritic cells in lymphoid and hematopoietic organs. J Exp Med. 1983; 158:1522-1536. [PubMed: 6355361]

Iavarone A, King ER, Dai XM, Leone G, Stanley ER, Lasorella A. Retinoblastoma promotes definitive erythropoiesis by repressing Id2 in fetal liver macrophages. Nature. 2004; 432:1040-1045. [PubMed: 15616565]

Jacks T, Fazeli A, Schmitt EM, Bronson RT, Goodell MA, Weinberg RA. Effects of an Rb mutation in the mouse. Nature. 1992; 359:295-300. [PubMed: 1406933]

Kansas GS, Muirhead MJ, Dailey MO. Expression of the CD11/CD18, leukocyte adhesion molecule 1, and CD44 adhesion molecules during normal myeloid and erythroid differentiation in humans. Blood. 1990; 76:2483-2492. [PubMed: 1702327] 
Kawane K, Fukuyama H, Kondoh G, Takeda J, Ohsawa Y, Uchiyama Y, Nagata S. Requirement of DNase II for definitive erythropoiesis in the mouse fetal liver. Science. 2001; 292:1546-1549. [PubMed: 11375492]

Keyhani E, Bessis M. Electron microscope study of the erythroblastic island using the cryo-scouring method. Nouv Rev Fr Hematol. 1969; 9:803-816. [PubMed: 4245041]

Kingsley PD, Malik J, Fantauzzo KA, Palis J. Yolk sac-derived primitive erythroblasts enucleate during mammalian embryogenesis. Blood. 2004; 104:19-25. [PubMed: 15031208]

Kondo M, Wagers AJ, Manz MG, Prohaska SS, Scherer DC, Beilhack GF, Shizuru JA, Weissman IL. Biology of hematopoietic stem cells and progenitors: Implications for clinical application. Annu Rev Immunol. 2003; 21:759-806. [PubMed: 12615892]

Konijn AM, Meyron-Holtz EG, Fibach E, Gelvan D. Cellular ferritin uptake: A highly regulated pathway for iron assimilation in human erythroid precursor cells. Adv Exp Med Biol. 1994; 356:189-197. [PubMed: 7887223]

Koury ST, Koury MJ, Bondurant MC. Morphological changes in erythroblasts during erythropoietininduced terminal differentiation in vitro. Exp Hematol. 1988; 16:758-763. [PubMed: 3169158]

Koury ST, Koury MJ, Bondurant MC. Cytoskeletal distribution and function during the maturation and enucleation of mammalian erythroblasts. J Cell Biol. 1989; 109:3005-3013. [PubMed: 2574178]

Kunisaki Y, Masuko S, Noda M, Inayoshi A, Sanui T, Harada M, Sasazuki T, Fukui Y. Defective fetal liver erythropoiesis and $\mathrm{T}$ lymphopoiesis in mice lacking the phosphatidylserine receptor. Blood. 2004; 103:3362-3364. [PubMed: 14715629]

Kurtz A, Hartl W, Jelkmann W, Zapf J, Bauer C. Activity in fetal bovine serum that stimulates erythroid colony formation in fetal mouse livers is insulin-like growth factor I. J Clin Invest. 1985; 76:1643-1648. [PubMed: 4056043]

Le Charpentier Y, Prenant M. [Isolation of erythroblastic islands. Study by optical and scanning electron microscopy (author's transl)]. Nouv Rev Fr Hematol. 1975; 15:119-140. [PubMed: 126418]

Lee EY, Chang CY, Hu N, Wang YC, Lai CC, Herrup K, Lee WH, Bradley A. Mice deficient for Rb are nonviable and show defects in neurogenesis and haematopoiesis. Nature. 1992; 359:288-294. [PubMed: 1406932]

Lee G, Lo A, Short SA, Mankelow TJ, Spring F, Parsons SF, Yazdanbakhsh K, Mohandas N, Anstee DJ, Chasis JA. Targeted gene deletion demonstrates that the cell adhesion molecule ICAM-4 is critical for erythroblastic island formation. Blood. 2006; 108:2064-2071. [PubMed: 16690966]

Lee JC, Gimm JA, Lo AJ, Koury MJ, Krauss SW, Mohandas N, Chasis JA. Mechanism of protein sorting during erythroblast enucleation: Role of cytoskeletal connectivity. Blood. 2004; 103:19121919. [PubMed: 14563645]

Lee SH, Crocker PR, Westaby S, Key N, Mason DY, Gordon S, Weatherall DJ. Isolation and immunocytochemical characterization of human bone marrow stromal macrophages in hemopoietic clusters. J Exp Med. 1988; 168:1193-1198. [PubMed: 3049905]

Liu XS, Luo HJ, Yang H, Wang L, Kong H, Jin YE, Wang F, Gu MM, Chen Z, Lu ZY, Wang ZG. Palladin regulates cell and extracellular matrix interaction through maintaining normal actin cytoskeleton architecture and stabilizing beta1-integrin. J Cell Biochem. 2007; 100:1288-1300. [PubMed: 17115415]

Matsushima T, Nakashima M, Oshima K, Abe Y, Nishimura J, Nawata H, Watanabe T, Muta K. Receptor binding cancer antigen expressed on SiSo cells, a novel regulator of apoptosis of erythroid progenitor cells. Blood. 2001; 98:313-321. [PubMed: 11435298]

McKnight AJ, Macfarlane AJ, Dri P, Turley L, Willis AC, Gordon S. Molecular cloning of F4/80, a murine macrophage-restricted cell surface glycoprotein with homology to the G-protein-linked transmembrane 7 hormone receptor family. J Biol Chem. 1996; 271:486-489. [PubMed: 8550607]

Mohandas N, Prenant M. Three-dimensional model of bone marrow. Blood. 1978; 51:633-643. [PubMed: 630113]

Naito M, Hasegawa G, Takahashi K. Development, differentiation, and maturation of Kupffer cells. Microsc Res Tech. 1997; 39:350-364. [PubMed: 9407545] 
Nemeth E, Tuttle MS, Powelson J, Vaughn MB, Donovan A, Ward DM, Ganz T, Kaplan J. Hepcidin regulates cellular iron efflux by binding to ferroportin and inducing its internalization. Science. 2004; 306:2090-2093. [PubMed: 15514116]

Nicolas G, Bennoun M, Devaux I, Beaumont C, Grandchamp B, Kahn A, Vaulont S. Lack of hepcidin gene expression and severe tissue iron overload in upstream stimulatory factor 2 (USF2) knockout mice. Proc Natl Acad Sci USA. 2001; 98:8780-8785. [PubMed: 11447267]

Orkin SH. Diversification of haematopoietic stem cells to specific lineages. Nat Rev Genet. 2000; 1:57-64. [PubMed: 11262875]

Palis J. Developmental biology: No red cell is an island. Nature. 2004; 432:964-965. [PubMed: 15616546]

Park CH, Valore EV, Waring AJ, Ganz T. Hepcidin, a urinary antimicrobial peptide synthesized in the liver. J Biol Chem. 2001; 276:7806-7810. [PubMed: 11113131]

Parker JE, Mufti GJ. Ineffective haemopoiesis and apoptosis in myelodysplastic syndromes. Br J Haematol. 1998; 101:220-230. [PubMed: 9609514]

Perry MM, John HA, Thomas NS. Actin-like filaments in the cleavage furrow of newt egg. Exp Cell Res. 1971; 65:249-253. [PubMed: 4101164]

Pevny L, Simon MC, Robertson E, Klein WH, Tsai SF, D’Agati V, Orkin SH, Costantini F. Erythroid differentiation in chimaeric mice blocked by a targeted mutation in the gene for transcription factor GATA-1. Nature. 1991; 349:257-260. [PubMed: 1987478]

Pevny L, Lin CS, D’Agati V, Simon MC, Orkin SH, Costantini F. Development of hematopoietic cells lacking transcription factor GATA-1. Development. 1995; 121:163-172. [PubMed: 7867497]

Pigeon C, Ilyin G, Courselaud B, Leroyer P, Turlin B, Brissot P, Loreal O. A new mouse liver-specific gene, encoding a protein homologous to human antimicrobial peptide hepcidin, is overexpressed during iron overload. J Biol Chem. 2001; 276:7811-7819. [PubMed: 11113132]

Policard A, Bessis M. Micropinocytosis and rhopheocytosis. Nature. 1962; 194:110-111. [PubMed: 14487564]

Qiu LB, Dickson H, Hajibagheri N, Crocker PR. Extruded erythroblast nuclei are bound and phagocytosed by a novel macrophage receptor. Blood. 1995; 85:1630-1639. [PubMed: 7888682]

Repasky EA, Eckert BS. A reevaluation of the process of enucleation in mammalian erythroid cells. Prog Clin Biol Res. 1981a; 55:679-692. [PubMed: 7197361]

Repasky EA, Eckert BS. Microtubules in mammalian erythroblasts. Are marginal bands present? Anat Embryol (Berl). 1981b; 162:419-424. [PubMed: 7347495]

Repasky EA, Eckert BS. The effect of cytochalasin B on the enucleation of erythroid cells in vitro. Cell Tissue Res. 1981c; 221:85-91. [PubMed: 7198511]

Rich IN, Vogt C, Pentz S. Erythropoietin gene expression in macrophages detected by in situ hybridization. Behring Inst Mitt. 1988a; 83:202-206. [PubMed: 2467647]

Rich IN, Vogt C, Pentz S. Erythropoietin gene expression in vitro and in vivo detected by in situ hybridization. Blood Cells. 1988b; 14:505-520. [PubMed: 3067782]

Rosemblatt M, Vuillet-Gaugler MH, Leroy C, Coulombel L. Coexpression of two fibronectin receptors, VLA-4 and VLA-5, by immature human erythroblastic precursor cells. J Clin Invest. 1991; 87:6-11. [PubMed: 1824634]

Rosse C. Small lymphocyte and transitional cell populations of the bone marrow; their role in the mediation of immune and hemopoietic progenitor cell functions. Int Rev Cytol. 1976; 45:155-290. [PubMed: 783066]

Sadahira Y, Mori M, Awai M, Watarai S, Yasuda T. Forssman glycosphingolipid as an immunohistochemical marker for mouse stromal macrophages in hematopoietic foci. Blood. 1988; 72:42-48. [PubMed: 2455574]

Sadahira Y, Mori M, Kimoto T. Isolation and short-term culture of mouse splenic erythroblastic islands. Cell Struct Funct. 1990; 15:59-65. [PubMed: 2187621]

Sadahira Y, Yasuda T, Kimoto T. Regulation of Forssman antigen expression during maturation of mouse stromal macrophages in haematopoietic foci. Immunology. 1991; 73:498-504. [PubMed: 1916901] 
Sadahira Y, Yoshino T, Monobe Y. Very late activation antigen 4-vascular cell adhesion molecule 1 interaction is involved in the formation of erythroblastic islands. J Exp Med. 1995; 181:411-415. [PubMed: 7528776]

Sadahira Y, Wada H, Manabe T, Yawata Y. Immunohistochemical assessment of human bone marrow macrophages in hematologic disorders. Pathol Int. 1999; 49:626-632. [PubMed: 10504523]

Sadahira Y, Yasuda T, Yoshino T, Manabe T, Takeishi T, Kobayashi Y, Ebe Y, Naito M. Impaired splenic erythropoiesis in phlebotomized mice injected with CL2MDP-liposome: An experimental model for studying the role of stromal macrophages in erythropoiesis. J Leukoc Biol. 2000; 68:464-470. [PubMed: 11037966]

Sangiorgi F, Woods CM, Lazarides E. Vimentin downregulation is an inherent feature of murine erythropoiesis and occurs independently of lineage. Development. 1990; 110:85-96. [PubMed: 1706980]

Sawada K, Krantz SB, Dessypris EN, Koury ST, Sawyer ST. Human colony-forming units-erythroid do not require accessory cells, but do require direct interaction with insulin-like growth factor I and/or insulin for erythroid development. J Clin Invest. 1989; 83:1701-1709. [PubMed: 2651478]

Schroeder TE. Actin in dividing cells: Contractile ring filaments bind heavy meromyosin. Proc Natl Acad Sci USA. 1973; 70:1688-1692. [PubMed: 4578441]

Simpson CF, Kling JM. The mechanism of denucleation in circulating erythroblasts. J Cell Biol. 1967; 35:237-245. [PubMed: 6061718]

Skutelsky E, Danon D. An electron microscopic study of nuclear elimination from the late erythroblast. J Cell Biol. 1967; 33:625-635. [PubMed: 6036525]

Skutelsky E, Danon D. Comparative study of nuclear expulsion from the late erythroblast and cytokinesis. Exp Cell Res. 1970; 60:427-436. [PubMed: 5422968]

Soni S, Bala S, Gwynn B, Sahr KE, Peters LL, Hanspal M. Absence of erythroblast macrophage protein (Emp) leads to failure of erythroblast nuclear extrusion. J Biol Chem. 2006; 281:2018120189. [PubMed: 16707498]

Spike BT, Macleod KF. The Rb tumor suppressor in stress responses and hematopoietic homeostasis. Cell Cycle. 2005; 4:42-45. [PubMed: 15611658]

Spike BT, Dibling BC, Macleod KF. Hypoxic stress underlies defects in erythroblast islands in the Rb null mouse. Blood. 2007; 110(6):2173-2181. [PubMed: 17557897]

Spring FA, Parsons SF, Ortlepp S, Olsson ML, Sessions R, Brady RL, Anstee DJ. Intercellular adhesion molecule-4 binds alpha(4)beta(1) and alpha (V)-family integrins through novel integrinbinding mechanisms. Blood. 2001; 98:458-466. [PubMed: 11435317]

Steiner R, Vogel H. On the kinetics of erythroid cell differentiation in fetal mice. I Microspectrophotometric determination of the hemoglobin content in erythroid cells during gestation. J Cell Physiol. 1973; 81:323-338. [PubMed: 4736586]

Tavassoli M. Embryonic and fetal hemopoiesis: An overview. Blood Cells. 1991; 17:269-281. discussion 282-266. [PubMed: 1912596]

Telen MJ. Erythrocyte adhesion receptors: Blood group antigens and related molecules. Transfus Med Rev. 2005; 19:32-44. [PubMed: 15830326]

Tober J, Koniski A, McGrath KE, Vemishetti R, Emerson R, de Mesy-Bentley KK, Waugh R, Palis J. The megakaryocyte lineage originates from hemangioblast precursors and is an integral component both of primitive and of definitive hematopoiesis. Blood. 2007; 109:1433-1441. [PubMed: 17062726]

Tordjman R, Delaire S, Plouet J, Ting S, Gaulard P, Fichelson S, Romeo PH, Lemarchandel V. Erythroblasts are a source of angiogenic factors. Blood. 2001; 97:1968-1974. [PubMed: 11264160]

Weiss MJ, Keller G, Orkin SH. Novel insights into erythroid development revealed through in vitro differentiation of GATA-1 embryonic stem cells. Genes Dev. 1994; 8:1184-1197. [PubMed: 7926723]

Whyatt DJ, Karis A, Harkes IC, Verkerk A, Gillemans N, Elefanty AG, Vairo G, Ploemacher R, Grosveld F, Philipsen S. The level of the tissue-specific factor GATA-1 affects the cell-cycle machinery. Genes Funct. 1997; 1:11-24. [PubMed: 9680325] 
Whyatt D, Lindeboom F, Karis A, Ferreira R, Milot E, Hendriks R, de Bruijn M, Langeveld A, Gribnau J, Grosveld F, Philipsen S. An intrinsic but cell-nonautonomous defect in GATA-1overexpressing mouse erythroid cells. Nature. 2000; 406:519-524. [PubMed: 10952313]

Wickremasinghe RG, Hoffbrand AV. Biochemical and genetic control of apoptosis: Relevance to normal hematopoiesis and hematological malignancies. Blood. 1999; 93:3587-3600. [PubMed: 10339463]

Williams BO, Schmitt EM, Remington L, Bronson RT, Albert DM, Weinberg RA, Jacks T. Extensive contribution of Rb-deficient cells to adult chimeric mice with limited histopathological consequences. EMBO J. 1994; 13:4251-4259. [PubMed: 7925270]

Wu L, de Bruin A, Saavedra HI, Starovic M, Trimboli A, Yang Y, Opavska J, Wilson P, Thompson JC, Ostrowski MC, Rosol TJ, Woollett LA, et al. Extra-embryonic function of Rb is essential for embryonic development and viability. Nature. 2003; 421:942-947. [PubMed: 12607001]

Yokoyama T, Kitagawa H, Takeuchi T, Tsukahara S, Kannan Y. No apoptotic cell death of erythroid cells of erythroblastic islands in bone marrow of healthy rats. J Vet Med Sci. 2002; 64:913-919. [PubMed: 12419868]

Yokoyama T, Etoh T, Kitagawa H, Tsukahara S, Kannan Y. Migration of erythroblastic islands toward the sinusoid as erythroid maturation proceeds in rat bone marrow. J Vet Med Sci. 2003; 65:449452. [PubMed: 12736425]

Yoshida H, Kawane K, Koike M, Mori Y, Uchiyama Y, Nagata S. Phosphatidylserine-dependent engulfment by macrophages of nuclei from erythroid precursor cells. Nature. 2005a; 437:754758. [PubMed: 16193055]

Yoshida H, Okabe Y, Kawane K, Fukuyama H, Nagata S. Lethal anemia caused by interferon-beta produced in mouse embryos carrying undigested DNA. Nat Immunol. 2005b; 6:49-56. [PubMed: 15568025] 


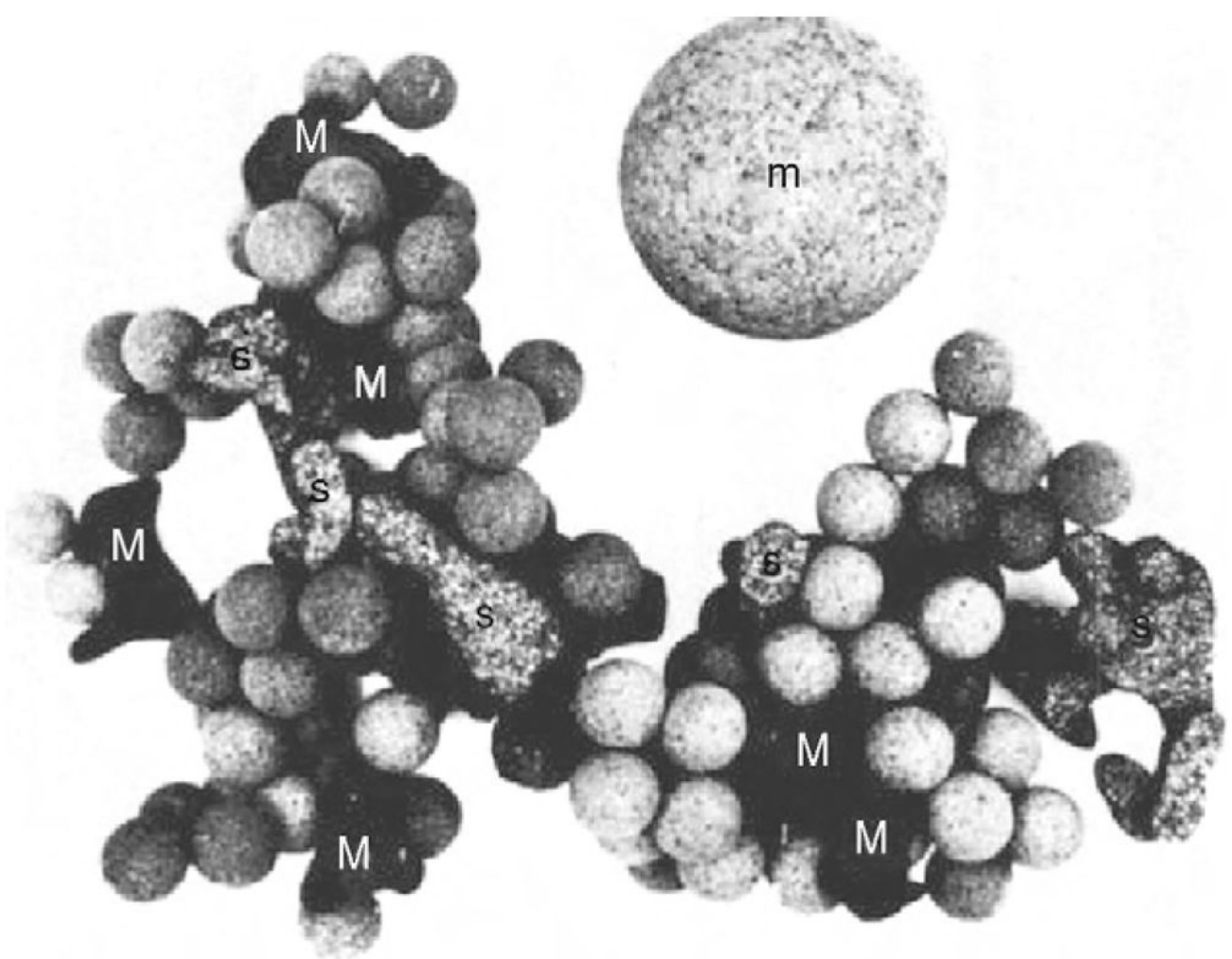

Figure 2.1.

A three-dimensional scale model of a small volume of bone marrow from normal rat is shown. In this model, the large sphere is a megakaryocyte (m), and also shown are sinuses (S), macrophages $(\mathrm{M})$, and the clusters of small spheres are the erythroblasts. This research was originally published in Blood (Mohandas and Prenant, 1978). (C) The American Society of Hematology. 


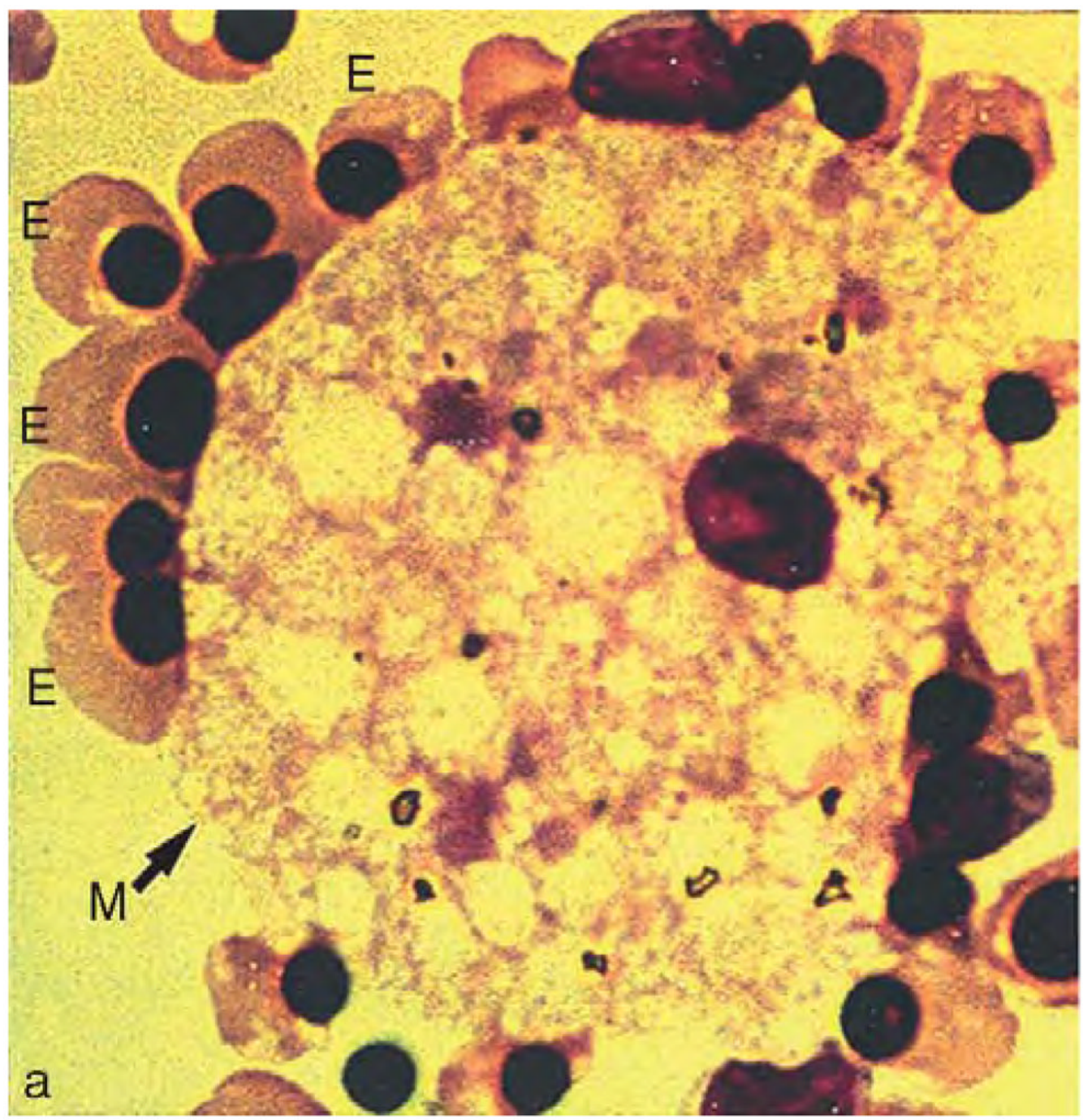

Figure 2.2.

Characteristic appearance of human erythroblastic island. A Wright-Giemsa stained, cytocentrifuged preparation of cells obtained from erythroblasts generated by in vitro culture of peripheral blood-derived mononuclear cells using two-phase liquid culture system was analyzed. An erythroblastic island consisting of a central macrophage (M) surrounded by a ring of late erythroblasts (E) on day 12 of the second phase of a macrophage-containing culture is shown. This research was originally published in Blood (Hanspal et al., 1998). () The American Society of Hematology. 


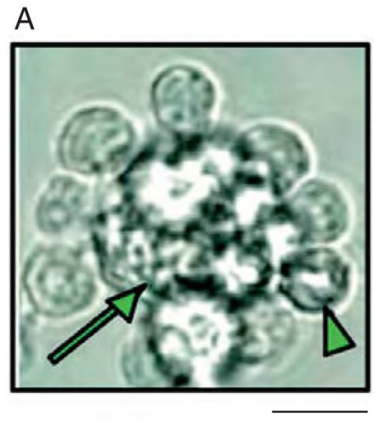

B

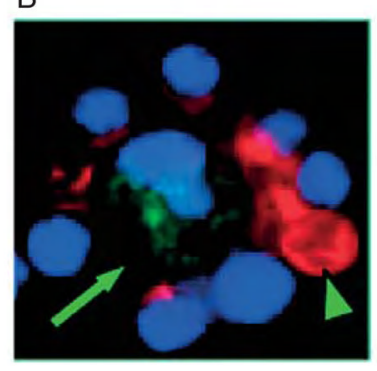

C

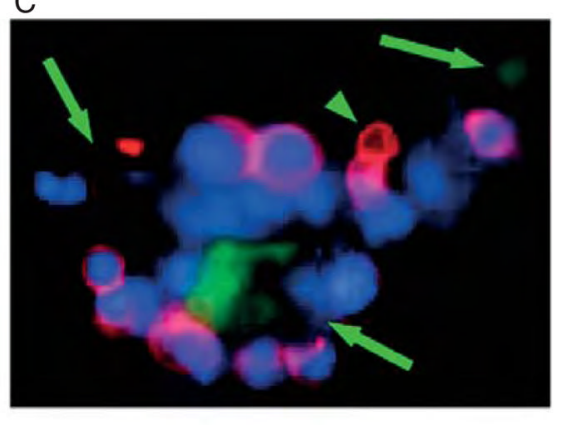

D

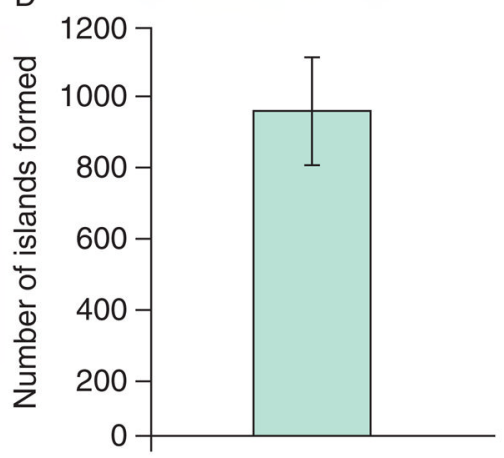

Figure 2.3.

Reconstituted erythroblastic islands. Bright field (A), immunofluorescent standard (B), and confocal (C) micrographs of typical erythroblastic islands formed from single-cell suspensions of MacGreen mouse bone marrow. Macrophages from MacGreen mice express the macrophage colony-stimulating factor (M-CSF) receptor-green fluorescent protein transgene, thereby providing a useful macrophage identifier. Results from an assay for reforming islands from single-cell suspensions of freshly harvested mouse bone marrow are depicted. Adults 3-5 months of age were used. A single-cell suspension was prepared, then cells were incubated for carefully controlled times in media containing manganese. Islands and their cellular components were identified by three-color immunofluorescence microscopy. Immunofluorescent micrographs of islands show cells stained for erythroidspecific marker GPA (Ter119; red), macrophage marker M-CSF receptor GFP transgene expression (green), and DNA (Hoechst 33342; blue). Because surface expression of glycophorin A increases during terminal differentiation, the intensity of Ter119 staining served as an effective indicator of erythroblast stage. A faint blush of Ter119 fluorescence was present in early erythroblasts and increasing degrees of staining were observed in progressively more differentiated cells. The fluorescence intensity of Ter119 label varied among erythroblasts in an individual island, indicating that islands were composed of erythroblasts at various stages of differentiation. Young, multilobulated reticulocytes were present in many islands, again consistent with prior descriptions of erythroblastic islands formed in vivo. In the confocal image, some of the cells appear blurred because they are not in the plane of focus. However, macrophage staining is apparent in various regions of the island. Reticulocytes, arrowheads; macrophage, arrows; bars represent $10 \mu \mathrm{m}$. (D) Histogram shows number of erythroblastic islands formed from $1 \times 105$ single cells; $n=10$. Results are shown as mean \pm SD. This research was originally published in Blood (Lee et al., 2006). () The American Society of Hematology. 


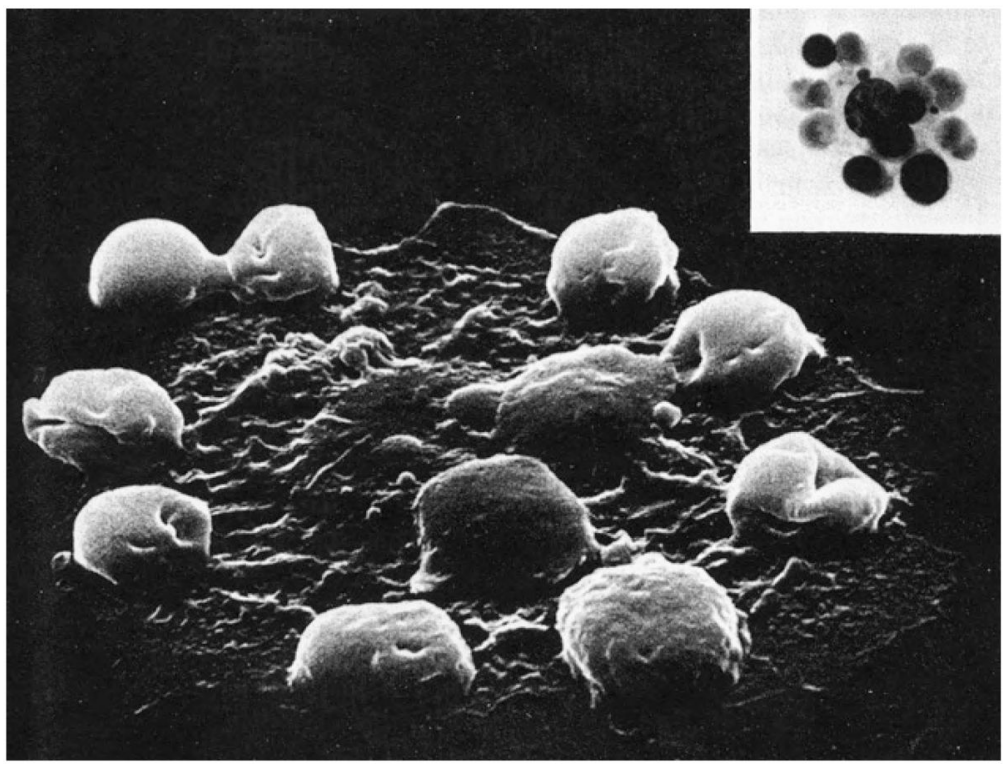

Figure 2.4.

Scanning electron micrography of an erythroblastic island from rat bone marrow. Erythroblastic island after 2 hours in vitro culture examined by scanning electron microscopy $(\times 5000)$. Top left insert: the same island seen with light microscopy (Giemsa $\times 1026$ ). Note the two nuclear extrusions, one early (bottom) and the other almost complete (top left). This research was originally published in Blood Cells (Marcel Bessis et al., 1978). (C) Springer-Verlag. 

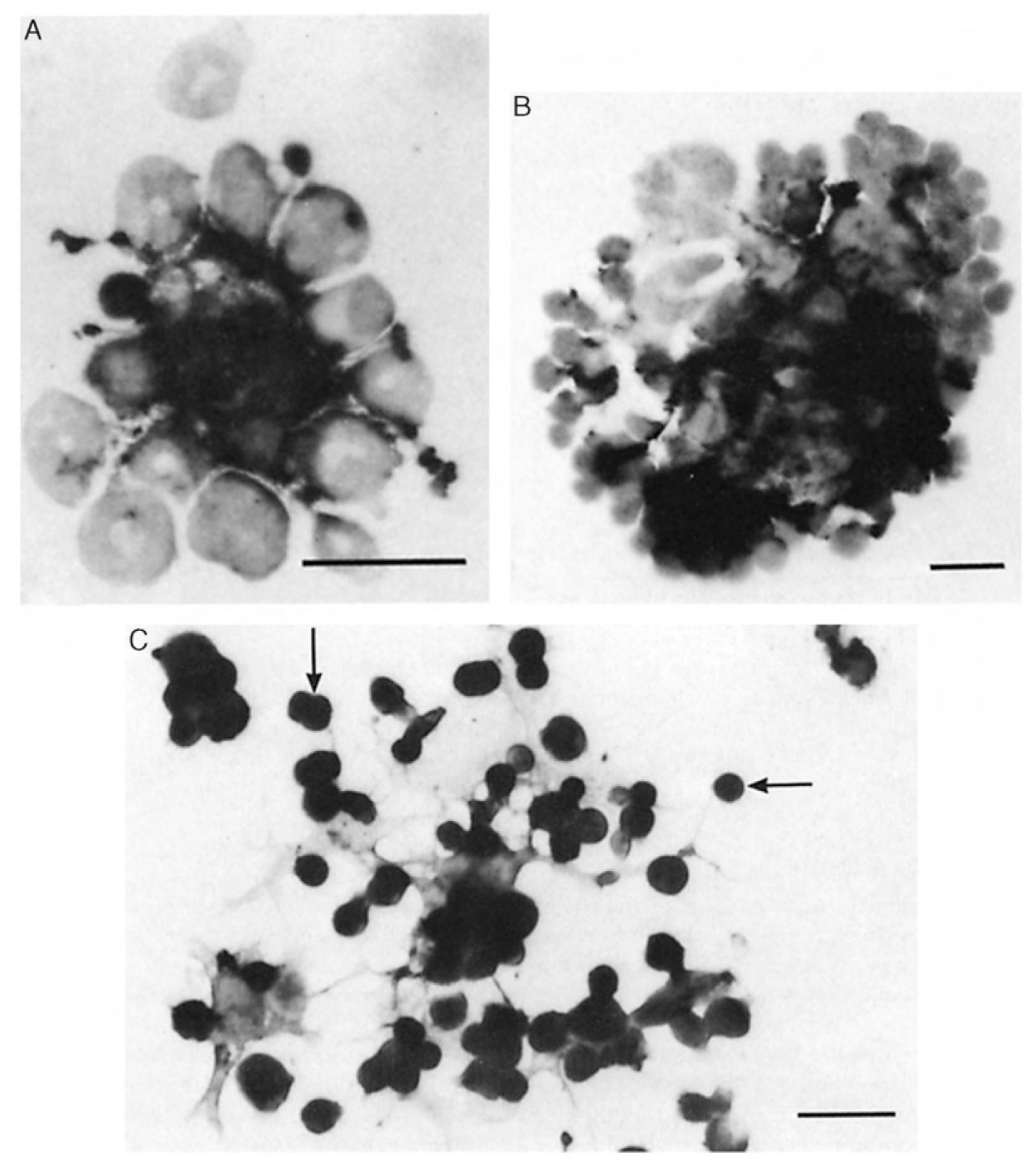

Figure 2.5.

Analysis of erythroblastic islands after collagenase digestion and cluster purification. Direct cytocentrifuge preparations (A and B) or following adherence of cells to glass coverslip (C) are shown. (A) Small cluster stained with Ab F4/80, counterstained with hematoxylin, showing central macrophage surrounded by erythroblasts. Microscopic analysis at different depths of focus indicated that a single macrophage was present in such clusters. (B) Large cluster stained with Ab F4/80, counterstained with hematoxylin, showing four to five macrophages with processes ramifying among clustering cells. It has been proposed that this may represent several erythroblastic islands clumped together. (C) Central macrophage stained with Ab F4/80 after adhesion to glass coverslip. Note that delicate macrophage processes ramify extensively, establishing intimate contact with hematopoietic cells distal from the macrophage cell body (arrow) and appear to cradle hematopoietic cells. Counterstained with hematoxylin. Bar, $10 \mu \mathrm{m}$. This research was originally published in $J$. Exp Med. (Crocker and Gordon, 1985). (C) The Rockefeller University Press. 
Table 2.1

Comparison of phenotype of central island macrophages and inflammatory peritoneal macrophages from C57BL/6 mice

\begin{tabular}{|llll|}
\hline & Number of experiments & Bone marrow island macrophage & Peritoneal macrophage \\
\hline Surface antigens: & & & ++ \\
F4/80 & $>20$ & +++ & ++ \\
Mac-1 (CR3) & 6 & - & ++ \\
FcR IgG1/IIb & 2 & +++ & \\
Surface receptors: & & & ++ \\
Zymosan (potent stimulator of phagocytosis and respiratory burst) & ++- \\
• Phagocytosis & 3 & +++ & ++ \\
$\bullet$ Respiratory burst & 2 & - & - \\
Complement & 3 & - & + \\
Sheep & $>20$ & +++ & + \\
Erythrocytes & & & +++ \\
FcR IgG2a/2b & 3 & ++ & + \\
\hline
\end{tabular}

This research is taken with permission from Crocker and Gordon(1985), @ The Rockefeller University Press. 
Table 2.2

Adhesion molecules and their interactions within the erythroblastic island

\begin{tabular}{|c|c|c|c|c|}
\hline Erythroblast adhesion molecule & Macrophage adhesion molecule & Erythroblast- erythroblast interaction & Erythroblast- macrophage interaction & References \\
\hline Emp & Emp & Yes & Yes & $\begin{array}{l}\text { Bala et al., } \\
2006 ; \\
\text { Hanspal et } \\
\text { al., 1998; } \\
\text { Soni et al., } \\
2006\end{array}$ \\
\hline $\begin{array}{l}\alpha 4 \beta 1 \text { integrin/very late antigen- } 4 \\
\text { (VLA-4) }\end{array}$ & VCAM-1 & & Yes & $\begin{array}{l}\text { Hamamura } \\
\text { et al., } \\
1996 ; \\
\text { Sadahira et } \\
\text { al., } 1995\end{array}$ \\
\hline ICAM-4 & $\alpha \mathrm{v}$ & & Yes & $\begin{array}{l}\text { Lee } \text { et al., } \\
2006 ; \\
\text { Spring } \text { et } \\
\text { al., 2001; } \\
\text { Telen, } \\
2005\end{array}$ \\
\hline ? & SER or sialoadhesion & & & $\begin{array}{l}\text { Crocker et } \\
\text { al., 1990; } \\
\text { Crocker } \\
\text { and } \\
\text { Gordon, } \\
1985,1986\end{array}$ \\
\hline$?$ & ED2 antigen & & & $\begin{array}{l}\text { Barbe } e t \\
\text { al., } 1996\end{array}$ \\
\hline$?$ & EbR & & & $\begin{array}{l}\text { Barbe et } \\
\text { al., } 1996\end{array}$ \\
\hline
\end{tabular}

EbR, Erythroblast receptor; Emp, Erythroblast macrophage protein; ICAM-4, intercellular adhesion molecule; SER, sheep erythrocyte receptor. 